\title{
Meiotic recombination in the $\beta$ globin gene cluster causing an error in prenatal diagnosis of $\beta$ thalassaemia
}

\author{
CLARA CAMASCHELlA*, ANNA SERRA*, GIUSEPPE SAGLiO*, \\ MARIA TIZIANA BERTERO*, UMBERTO MAZZA*, \\ SEVERINA TERZOLI $\dagger$, BRUNO BRAMBATI , LAURA CREMONESI§, \\ MAURIZIO TRAVI§, AND MAURIZIO FERRARI§ \\ From *Clinica Medica A, Dipartimento di Scienze Biomediche ed Oncologia Umana, Università di Torino; \\ †I Clinica Pediatrica and $\ddagger$ I Clinica Ostetrica e Ginecologica, Università di Milano; and §Laboratorio di \\ Ricerche Cliniche, Istituti Clinici di Perfezionamento, Milano, Italy.
}

SUMMARY In the course of a prenatal diagnosis for $\beta$ thalassaemia by linkage analysis of restriction fragment length polymorphisms, a homozygous $\beta$ thalassaemia fetus was misdiagnosed as $\beta$ thalassaemia trait.

Extensive studies of the polymorphic sites within the $\beta$ globin gene cluster in all the members of the family resulted in the conclusion that the paternal chromosome 11 of the newborn was different from that expected. Paternity was confirmed by HLA typing and blood group studies.

The analysis of another polymorphic locus on chromosome 11 within the family was in agreement with the possibility of a crossing over between the two paternal chromosomes in a region $5^{\prime}$ to the $\beta$ gene, previously indicated to contain a 'hot spot' area for recombination.

This report underlines the risk of performing prenatal diagnosis using restriction polymorphisms $5^{\prime}$ to the $\beta$ gene.

First trimester prenatal diagnosis is accomplished in a variety of hereditary disorders by linkage analysis using restriction fragment length polymorphisms (RFLPs) as markers of the chromosome carrying the abnormal gene. ${ }^{1-3}$ This indirect method is convenient in diseases heterogeneous at the molecular level, since it does not require direct identification of the molecular lesions and has been successfully applied to a wide range of diseases. ${ }^{3-6}$

$\beta$ thalassaemia shows remarkable molecular heterogeneity: in Italy at least eight defects have been described ${ }^{7}$ and the majority of patients are compound heterozygotes for two different mutations. ${ }^{8}$ To circumvent the problem of simultaneous identification of two different thalassaemic defects in the fetus, a plan of prenatal diagnosis was organised in northern Italy based upon indirect assay using polymorphic restriction sites in the $\beta$ globin cluster. ${ }^{910}$

This procedure always carries some degree of risk of recombination between the mutated gene and the

Received for publication 6 April 1987.

Revised version accepted for publication 15 May 1987. polymorphisms analysed. Considering the distance between the polymorphic sites used and the $\beta$ gene, the theoretical risk should be approximately 1:2000. ${ }^{11}$ Nevertheless, previous population studies on the association of polymorphic sites in this region suggested that the recombination rate in a $9 \mathrm{~kb}$ region $5^{\prime}$ to the $\beta$ gene could be greater than expected. ${ }^{7} 1213$ Furthermore, at least two examples of meiotic recombination have been described up to now. ${ }^{14} 15$

In this paper we report an error which occurred during prenatal diagnosis of $\beta$ thalassaemia by RFLP linkage analysis: a homozygous $\beta$ thalassaemic child was born who had been diagnosed as $\beta$ thalassaemia trait in the first trimester of pregnancy. The results obtained by studying the inheritance of several RFLPs in chromosome 11 within the family suggest that meiotic recombination in the father is the most likely explanation of this event.

\section{Material and methods}

DNA was prepared from peripheral blood of an Italian couple at risk for $\beta$ thalassaemia, who 
requested prenatal diagnosis in the seventh week of gestation, and of their child with Cooley's anaemia (fig 1).

DNA $(10 \mu \mathrm{g})$ was digested with restriction endonucleases HindIII, HincII, AvaII, and BamHI. DNA fragments were separated on $0.8 \%$ agarose gels and transferred onto nitrocellulose filters. ${ }^{8}$ The

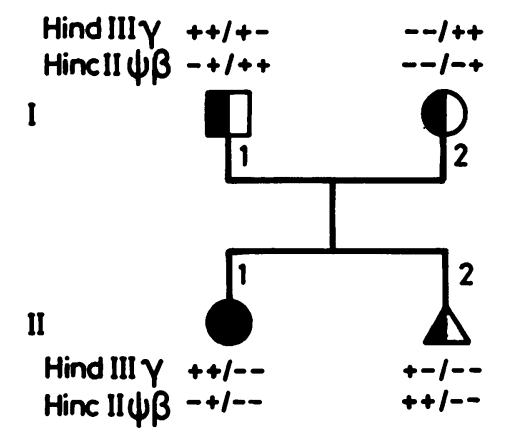

\section{Heterozygous for $\beta$ thalassaemia \\ Homozygous for $\beta$ thalassaemia \\ $\triangle$ Fetus}

FIG 1 Family pedigree. Informative polymorphic sites used for prenatal diagnosis (HindIII $\gamma$ and HincII $\psi \beta$ ) are indicated. + indicates the presence and - the absence of the polymorphism. filters were hybridised to genomic probes corresponding to the globin genes. Eight polymorphic sites in the $\beta$ like globin cluster ${ }^{12} 16$ were used to assess the feasibility of prenatal diagnosis (fig 2).

Fetal DNA was prepared from chorionic villi ${ }^{17}$ obtained by the aspiration technique in the ninth week of gestation. Both HindIII $\gamma$ and HincII $\psi \beta$ sites, $5^{\prime}$ to the $\beta$ gene, were analysed in fetal DNA.

Other polymorphic sites studied were the TaqI $5^{\prime} \delta$, the PstI at the $\delta$ gene level, and the HindIII $3^{\prime} \beta^{18}$ in the $\beta$ globin gene cluster and the polymorphic Ha-ras locus on chromosome $113^{\prime}$ to the $\beta$ globin gene (fig 2); the latter was analysed by the AvaII restriction enzyme. ${ }^{19}$

Paternity was assessed by traditional blood grouping and HLA typing.

Haemoglobin isoelectric focusing ${ }^{20}$ and globin chain synthesis ${ }^{21}$ were performed on the cord blood.

\section{Results}

The feasibility of prenatal diagnosis was $100 \%$ with the use of either HindIII $\gamma$ or HincII $\psi \beta$ polymorphic sites: the analysis of both these polymorphisms led to a diagnosis of a heterozygous $\beta$ thalassaemia fetus (fig 1).

At birth, no haemoglobin A was detectable on isoelectric focusing of the cord blood, and globin chain synthesis on the peripheral blood of the newborn revealed no $\beta$ chain production. Moreover, within three months II. 2 developed a clear picture of Cooley's anaemia, requiring blood transfusions.

$\mapsto \mathrm{KKb}$

B Globin gene cluster

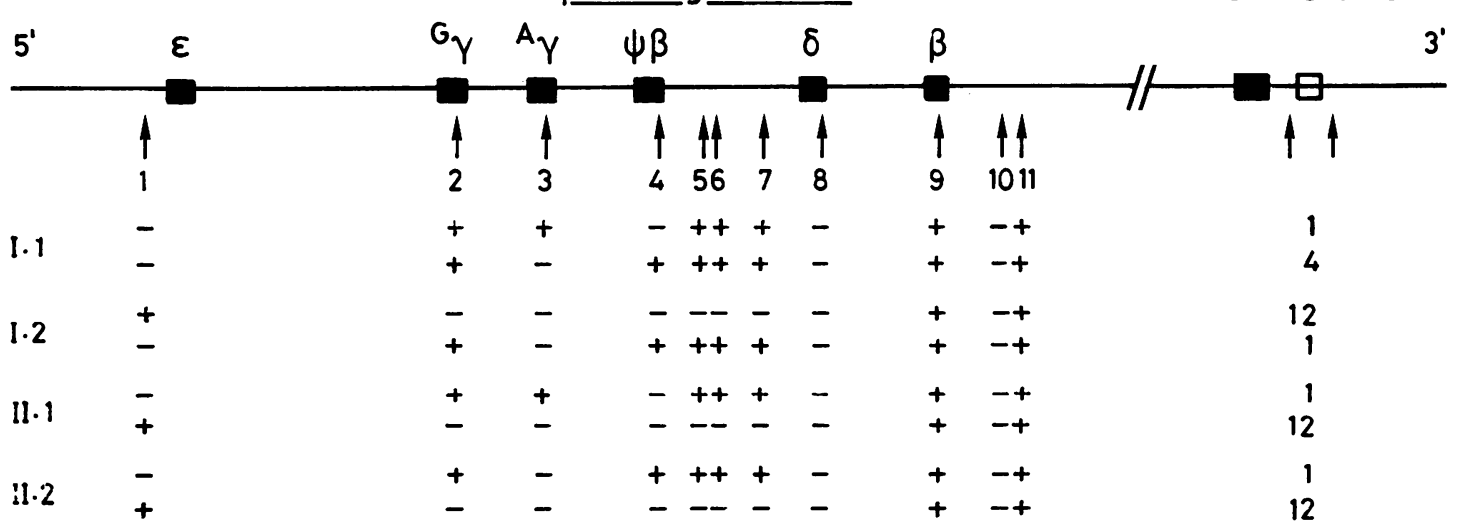

FIG 2 Map of the $\beta$ globin gene cluster and of the Ha-ras locus on chromosome 11. Arrows indicate the polymorphic restriction sites examined. $1=$ HincII $\varepsilon, 2=H$ indIII $G \gamma, 3=H$ indIII $A \gamma, 4=H$ incII $\psi \beta, 5=H$ incII $3^{\prime} \psi \beta, 6=A$ vall $\psi \beta$, $7=$ TaqI $5^{\prime} \delta, 8=$ Pst $\delta, 9=A$ valI $\beta, 10=$ HindIII $3^{\prime} \beta, 11=B a m H I 3^{\prime} \beta$. The sites $1-6$, 9, and 11 are usually studied to assess the feasibility of prenatal diagnosis of $\beta$ thalassaemia. Below: results of polymorphism analysis in all the members of the family (see fig 1) $++=$ presence and $-=$ absence of the polymorphism. Numbers indicate different sized Ha-ras Avall alleles: $1=1 \cdot 5 \mathrm{~kb}, 4=2 \cdot 1 \mathrm{~kb}, 12=3 \cdot 1 \mathrm{~kb}$. 
To rule out technical errors, blood was again obtained from all the members of the family and the newborn; previous results were confirmed.

Non-paternity was taken into account and investigated by HLA typing and blood group studies: the segregation of alleles at several polymorphic loci (HLA-A, B, C, DR, ABO, Rh, MN) was in agreement with correct paternity.

The pattern of polymorphic sites in the $\beta$ globin cluster showed that II. 2 had inherited the maternal $\beta$ thalassaemic chromosome, as expected, and a paternal chromosome different from that inherited by the similarly affected sister (II.1) (fig 2).

Interestingly, the HindIII $\gamma$ and HincII $\psi \beta$ polymorphisms in the paternal chromosome of II.2 correspond to those present in the $5^{\prime}$ region of the 'normal' chromosome of I.1. Since II.2 has no normal $\beta$ genes, this event could have occurred because of a meiotic recombination between the two paternal chromosomes.

To confirm this possibility, the pattern of inheritance of a polymorphic locus $3^{\prime}$ to the $\beta$ gene (the Ha-ras proto-oncogene) was studied. Different Haras alleles are observed in normal populations, related to tandemly repeated sequences of variable length $3^{\prime}$ to the coding sequences of the Ha-ras locus. ${ }^{19}$ This was also the case in our family, since the parental chromosomes could be distinguished by this polymorphism (fig 2). This study showed that II. 1 and II. 2 have inherited the same maternal and paternal Ha-ras alleles.

In order to define the boundaries of the hypothesised crossing over, other polymorphisms in the $\beta$ globin region were examined. However, this did not provide any additional information, since the father was homozygous for the presence of the TaqI $5^{\prime} \delta$ and the absence of the PstI $\delta$ and the HindIII $3^{\prime} \beta$ sites (fig 2).

\section{Discussion}

In the family studied, two sisters, both homozygous for $\beta$ thalassaemia, have unequivocally different genetic markers in the region of the paternal chromosome $11,5^{\prime}$ to the $\beta$ thalassaemia gene. As non-paternity can be confidently excluded, there are a number of different possibilities that could theoretically explain this fact.

The first is a new $\beta$ thalassaemia mutation in the 'normal' chromosome of the father. We have no direct proof that the $\beta$ thalassaemia mutation inherited from the father is indeed the same in II.1 and II.2, so the hypothesis of a new $\beta$ thalassaemia mutation in the 'normal' paternal chromosome cannot be ruled out. However, this possibility is unlikely, since new mutations in $\beta$ thalassaemia are extremely rare and up to now only one case has been demonstrated at the molecular level. ${ }^{22}$

A more realistic explanation is a meiotic recombination, either a gene conversion or a crossing over between the two paternal chromosomes 11 .

A single gene conversion event does not explain the simultaneous variation at the HindIII $\mathrm{A} \gamma$ and HincII $5^{\prime} \psi \beta$ sites, since they are at least $6 \mathrm{~kb}$ apart. On the other hand, a conversion of the normal gene into a $\beta$ thalassaemia one is ruled out by the Ha-ras polymorphism inheritance within the family. As shown in fig 2 the same Ha-ras alleles were found in II.1 and II.2, suggesting that both have inherited the same paternal thalassaemic chromosome. This finding is in agreement with the hypothesis of a crossing over in the region of the paternal chromosome $5^{\prime}$ to the $\beta$ gene. Since the other polymorphisms examined between the $\psi \beta$ and $\beta$ gene were not informative, the boundaries of the hypothesised crossover remain wide (fig 3): the event could have occurred at any site in the region between the $\psi \beta$ gene and the $\beta$ thalassaemia mutation, joining the $5^{\prime}$ region of the originally 'normal' chromosome to the $\beta$ thalassaemic chromosome.

We could not establish whether crossing over took place in II. 2 or in II.1, since no other member of the paternal family was available to assess the usual polymorphism pattern linked to the $\beta$ thalassaemic mutation.

At least two other recent cases of recombination in the approximately $9 \mathrm{~kb}$ 'hot spot' region of the $\beta$
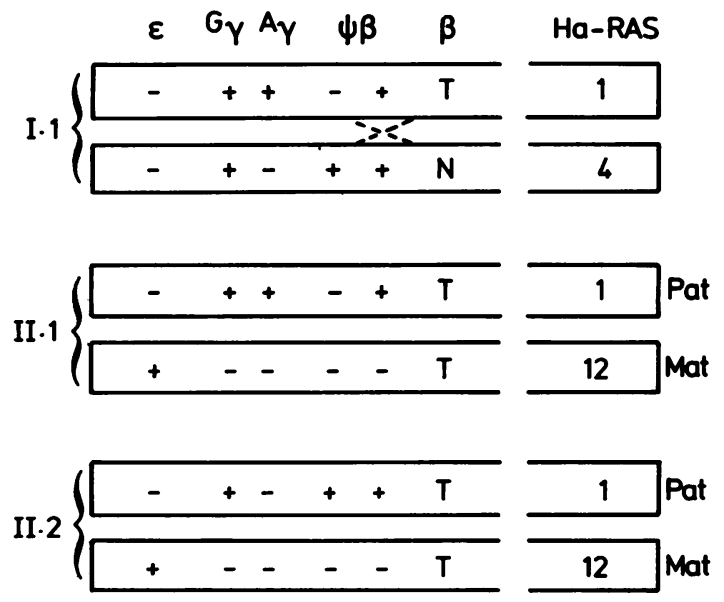

FIG 3 Schematic representation of the chromosomes 11 of $I .1,11.1$, and II.2. The difference in the polymorphisms $5^{\prime} \beta$ in II. 1 and II. 2 is evident. The boundaries of the hypothesised crossover between the paternal chromosomes are indicated by a dotted line. 

nowin gene cluster have been reported up to

It therefore appears evident that meiotic recombination may be a relevant cause of unpredictable error in prenatal diagnosis of $\beta$ thalassaemia by RFLP analysis. Unfortunately, the informative sites, at least in the Italian couples, lie in the region $5^{\prime}$ to the $\beta$ gene in $71 \%$ of cases (Ferrari et al, unpublished data); this fact must be taken into account when planning prenatal diagnosis. Further studies are needed to quantify the risk for genetic counselling. In the meantime, control by fetoscopy and globin chain synthesis may be proposed for fetuses diagnosed as $\beta$ thalassaemia heterozygotes by RFLPs $5^{\prime}$ to the $\beta$ gene. It might also be advisable, whenever possible, to check prenatal diagnosis using polymorphisms at the $\beta$ gene level or $3^{\prime}$ to it, since recombination rates for this region have been found to be lower. ${ }^{13}$

We thank Professor R Ceppellini for comments and suggestions and Centro Trasfusionale Istituto Ortopedico G Pini, Milano for paternity studies. This work was supported in part by CNR Rome Grant No 85.00701.04 to UM and Regione Piemonte Ricerca Finalizzata No 32, 1984. A Serra was supported by a fellowship from Associazione Talassemici Torino.

\section{References}

1 Kan YW, Dozy AM. Polymorphism of DNA sequence adjacent to human $\beta$-globin structural gene: relationship to sickle mutation. Proc Natl Acad Sci USA 1978;76:5631-5.

${ }^{2}$ Kan YW, Lee KY, Furbetta M, Angius A, Cao A. Polymorphism in DNA sequence in the $\beta$ globin region: application to prenatal diagnosis of $\beta$-thalassemia in Sardinia. $N$ Engl $J$ Med 1980;302:185-8.

${ }^{3}$ Boehm CD, Antonarakis SE, Phillips JA, Stetten G, Kazazian HH Jr. Prenatal diagnosis using DNA polymorphisms. $N$ Engl J Med 1983;306:1054-8.

4 Antonarakis S, Copeland KL, Carpenter RJ, et al. Prenatal diagnosis of haemophilia A by factor VIII gene analysis. Lancet 1985;i:1407-9.

5 Bakker E, Goor N, Wrogemann K, et al. Prenatal diagnosis and carrier detection of Duchenne muscular dystrophy with closely linked RFLPs. Lancet 1985;i:655-8.

${ }^{6}$ Lidsky AS, Guttler F, Woo SLC. Prenatal diagnosis of classic phenylketonuria by DNA analysis. Lancet 1985;i:549-51.

7 Orkin SH, Kazazian HH Jr, Antonarakis SE, et al. Linkage of $\beta$-thalassaemia mutation and $\beta$ globin gene polymorphisms with DNA polymorphisms in human $\beta$ globin gene cluster. Nature 1982;296:627-31.

* Pirastu M, Saglio G, Camaschella C, et al. Delineation of specific $\beta$-thalassemia mutations in high risk areas of Italy: a prerequisite for prenatal diagnosis. Blood (in press).

${ }^{9}$ Camaschella C, Saglio G, Serra A, et al. DNA polymorphism analysis in the Italian population and prenatal diagnosis of thalassemia. In: Fraccaro $\mathrm{M}$, et al, eds. First trimester fetal diagnosis. Berlin: Springer Verlag, 1985:276-82

${ }^{10}$ Camaschella C, Saglio G, Serra A, Cremonesi L, Travi M, Ferrari M. Fetal diagnosis of $\beta$-thalassaemia bỳ DNA analysis in Italy. Lancet 1986;i:390.

1 Kurnit DM, Hoehn H. Prenatal diagnosis of human genome variation. Annu Rev Genet 1979;13:235-8.

12 Antonarakis SE, Boehm CD, Giardina PJV, Kazazian HH Jr. Non-random association of polymorphic restriction sites in the $\beta$-globin gene cluster. Proc Natl Acad Sci USA 1982;79:137-41.

13 Chakravarti A, Buetow KH, Antonarakis SE, Waber PGG, Boehm CD, Kazazian HH. Non uniform recombination within the human $\beta$-globin gene cluster. Am J Hum Genet 1984;36: 1239-58.

14 Gerhard DS, Kidd KK, Kidd JR, Egeland A, Housman DE. Identification of a recent recombination event within the human $\beta$-globin gene cluster. Proc Natl Acad Sci USA 1984;81:7875-9.

15 Old JM, Heath C, Fitches A, et al. Meiotic recombination between two polymorphic restriction sites within the $\beta$ globin gene cluster. J Med Genet 1986;23:14-8.

16 Wainscoat JS, Thein SL, Old JM, Weatherall DJ. A new DNA polymorphism for prenatal diagnosis of $\beta$-thalassaemia in Mediterranean population. Lancet 1984;ii:1299-301.

17 Goossens M, Dmez Y, Kaplan L, et al. Prenatal diagnosis of sickle cell anemia in the first trimester of pregnancy. $N$ Engl $J$ Med 1983;309:831-3.

18 Tuan D, Feingold E, Newman M, Weissman SM, Forget BG. Different $3^{\prime}$ end points of deletions causing $\delta \beta$-thalassemia and hereditary persistence of fetal hemoglobin: implication for the control of $\gamma$-globin gene expression in man. Proc Natl Acad Sci USA 1983;80:6937-41.

19 Thein SL, Oscier DG, Flint J, Wainscoat JS. Ha-ras hypervariable alleles in myelodysplasia. Nature 1986;321:84-5.

21) Ferrari M, Crema A, Cantu-Rajnoldi A, et al. Antenatal diagnosis of haemoglobinopathies by improved method of isoelectric focusing of haemoglobins. Br J Haematol 1984;57: 265-70.

21 Clegg JB, Naughton MA, Weatherall DJ. Abnormal human hemoglobin. Separation and characterization of $\alpha$ and $\beta$ chains by chromatography and the determination of two new $\alpha$ chain variants $\mathrm{Hb}$ Chesapeake and $\mathrm{Hb} \mathrm{J}$ (Bangkok). J Mol Biol 1966;240:190-7.

${ }^{22}$ Chehab FF, Honig GR, Kan YW. Spontaneous mutation in $\beta$ thalassaemia producing the same nucleotide substitution as that in a common hereditary form. Lancet 1986;i:3-6.

Correspondence and requests for reprints to $\mathrm{Dr} C$ Camaschella, Clinica Medica A, Dipartimento di Scienze Biomediche ed Oncologia Umana, Via Genova 3, 10126 Torino, Italy. 